\title{
Blood titanium level as a biomarker of orthopaedic implant wear
}

\author{
Ilona Swiatkowska ${ }^{1}$, Nicholas Martin ${ }^{2}$, Alister J. Hart ${ }^{1,3}$ \\ ${ }^{1}$ Institute of Orthopaedics and Musculoskeletal Science, University College London, HA7 \\ 4LP Stanmore, UK \\ ${ }^{2}$ Trace Element Laboratory, Clinical Biochemistry, Charing Cross Hospital, W6 8RF \\ London, UK \\ ${ }^{3}$ Royal National Orthopaedic Hospital, Stanmore, HA7 4LP Stanmore, UK \\ Correspondence and requests for materials should be addressed to I.S. (email: \\ ilona.swiatkowska.10@ucl.ac.uk, phone number: 0208416 3412)
}

\begin{abstract}
Background: Joint replacement implants are usually manufactured from cobalt-chromium or titanium alloys. After the device is implanted, wear and corrosion generate metal particles and ions, which are released into local tissue and blood. The metal debris can cause a range of adverse local and systemic effects in patients.
\end{abstract}

Research problem: In the case of cobalt and chromium, a blood level exceeding $7 \mu \mathrm{g} \mathrm{L}^{-1}$ indicates potential for local toxicity, and a failing implant. It has been repeatedly suggested in the literature that measurement of titanium could also be used to assess implant function. Despite an increasing interest in this biomarker, and growing use of titanium in orthopaedics, it is unclear what blood concentrations should raise concerns. This is partly due to the technical challenges involved in the measurement of titanium in biological samples.

Aim: This Review summarises blood/serum titanium levels associated with well-functioning and malfunctioning prostheses, so that the prospects of using titanium measurements to gain insights into implant performance can be evaluated.

Conclusion: Due to inter-laboratory analytical differences, reliable conclusions regarding "normal" and "abnormal" titanium levels in patients with orthopaedic implants are difficult to draw. Diagnosis of symptomatic patients should be based on radiographic evidence combined with blood/serum metal levels. 


\section{INTRODUCTION}

Joint arthroplasty is a successful and cost-effective way to relieve arthritic pain and improve quality of life of its recipients [1]. The procedure involves removing either part, or all, of the diseased joint surface, and replacing it with synthetic components. In general, hip implants consist of two basic parts: the ball (femoral head), which is manufactured from metal or ceramic, and the socket (acetabular cup), which can be made of polyethylene, ceramic or metal. In total hip arthroplasty (THA), a long metal stem is inserted into the femur, which connects with the femoral head via a tapered neck. This is in contrast to hip resurfacing (HR), whereby the patient's femur is simply reshaped and capped with a metal covering. Knee implants are comprised of a metal femoral component and a polyethylene tibial component, which, in some designs, is supported by a metal backing. Depending on the material combination used in the articulation, joint implants are classified as metal-on-plastic (MoP), ceramic-on-plastic (CoP), ceramic-on-ceramic $(\mathrm{CoC})$, or metal-on-metal $(\mathrm{MoM})$.

Titanium (Ti) and its alloys are being used in the production of many different medical devices, including joint replacement implants [2-5]. The metal has been praised for its superior physicochemical properties, corrosion-resistance [6] and biocompatibility. However, a number of recent studies suggest that titanium-based implants exhibit wear and/or corrosion in physiological environments [7,8], releasing pro-inflammatory byproducts into the surrounding tissue [9-13] and blood [14,15]. Unlike cobalt, titanium is highly insoluble, and not readily excreted in the urine. Instead, it gradually accumulates in distal organs [16-19], which can lead to tissue injury [17,20-25]. Despite the emerging safety concerns, the metal has so far received relatively little attention. The exact mechanism of titanium release from implants, the identity of the species released (particles vs ions), and their cellular fate is unclear. The baseline and toxic levels of titanium in biological fluids also remain unestablished, due to the poor availability of reliable methods of detection. Even though high 
resolution instruments were recently shown to accurately measure titanium concentration in the blood, they are only offered in a handful of specialised laboratories, making routine monitoring difficult.

As the number of joint replacements continues to increase every year, the use of titanium in total joint arthroplasty (TJA) is predicted to rise. Blood titanium level could potentially be used to monitor implant performance and help identify malfunctioning prostheses before they fail. In this Review, we sought to give a detailed account of titanium in TJA, and summarise the blood levels associated with well-functioning and malfunctioning prostheses, so that clinical utility of blood titanium monitoring can be evaluated.

\section{RELEASE OF TITANIUM FROM JOINT IMPLANT COMPONENTS}

Titanium is regarded as one of the safest and most biocompatible implant materials, and is used extensively in orthopaedics- mainly in the production of femoral stems, acetabular cups and metal backing of tibial components. Since pure titanium is relatively soft, it is often combined with other metals to increase its strength and rigidity. The most popular choices include titanium 6-aluminium 4-vanadium (TiAlV) and titanium 6-aluminium 7-niobium (TiAlNb) alloys [26]. Owing to a layer of titanium dioxide $\left(\mathrm{TiO}_{2}\right)$ that spontaneously forms on the surface of the metal, titanium and its alloys are highly resistant to corrosion [6]. However, once the implant is inserted, mechanical forces can easily degrade this protective film and expose the underlying metal to the aggressive body fluids. Corrosion and wear, or a synergistic combination of the two, liberates complex degradation products including titanium particles, metal-protein complexes, inorganic salts and ions. These can pass into the adjacent tissue, synovial fluid and blood, and be disseminated around the body. The predominant degradation mode for titanium acetabular cups is passive corrosion [27], while femoral stems can undergo a combination of various corrosion and wear mechanisms, depending on the component interface (stem-bone, stem-head, neck-stem). Modular stems, 
which feature an interchangeable femoral neck component that connects the stem and the head, are notorious for their high metal release at the neck-stem interface [28]. The amount, and toxic profile, of the metal debris released at this junction seems to depend on the material combination. $\mathrm{CoCr} / \mathrm{Ti}$ junctions were shown to release more metallic debris compared to alltitanium connections [29], with the debris having more potential to cause adverse tissue reactions [30-32]. This might be due to the fact that $\mathrm{CoCr} / \mathrm{Ti}$ junctions release mostly cobalt and chromium ions, which are more pro-inflammatory and toxic than titanium ions [33]. The amount of debris released at the different junctions, and its physicochemical characteristics, are dependent on several factors, including implant type, its positioning, the exact degradation mechanisms at play, as well as the patient's physical activity and state of health [34-36]. Particles generated through different wear processes can display different elemental composition [37], crystal structure [38,39], size [40-42] and shape [43], which might result in differing bioactivity. Nanoparticles are thought to be generally more dangerous than coarser particles [44,45], because they enter cells more easily and are more reactive, owing to the larger surface area-to-volume ratio [46]. Studies of tissues surrounding failed hip and knee implants revealed that majority of titanium-based wear debris is of submicron size $[17,47,48]$.

\section{ADVERSE EFFECTS OF TITANIUM DEBRIS}

The poor water solubility of titanium is often considered as an indicator of its biological inertness. However, studies and case reports of patients with malfunctioning titanium implants reveal a range of adverse effects associated with this metal, including inflammation [49], pain [8], cytotoxicity [50,51], metal allergy [52,53], genotoxicity [54], carcinogenicity [55] and implant failure [56]. The most widely researched effects of titanium are those on the bone cells- osteoblasts (bone-forming) and osteoclasts (bone-resorbing) [42,53,57,58].

Soluble and particulate titanium disturbs the delicate balance between the two cell types, 
resulting in bone loss and implant loosening, which often necessitates a redo surgery (revision surgery) [35,41,56,59-61]. Formation of large inflammatory masses (pseudotumours) in the vicinity of the implant, originally thought to be an immune response unique to $\mathrm{CoCr}$ alloy, was recently linked to titanium release [62-64]. The pathogenesis of pseudotumor formation is unknown, but it is thought to involve both a chronic inflammatory response and a delayed hypersensitivity response to ultrafine titanium particles [62]. It follows that individuals with a pre-existing titanium sensitivity might be at a greater risk of this particular complication [64]. The toxic effects of titanium are not restricted to the local hip environment. As wear particles are ingested by macrophages and enter the lymphatic system, they can be distributed into all tissues and organs $[17,65]$. Titanium ions $\left(\mathrm{Ti}^{4+}\right)$ bind to transferrin in the human serum, which also allows them to be transported to different parts of the body [66]. The transferrin-titanium complex can enter cells and influence their metabolism [67], though the intracellular fate of $\mathrm{Ti}^{4+}$, and how it exerts its effects, remain largely unknown [68]. Titanium alloys may also be a source of $\mathrm{TiO}_{2}$ [69]. Exposure to $\mathrm{TiO}_{2}$ nanoparticles was linked to cardiac inflammation [22,70], brain damage [71], impairment of spatial recognition memory [72] and learning abilities [73] in mice. Concerns have also been raised over possible genotoxicity and carcinogenicity of titanium debris [74]. Titanium is a redox-active metal that can enhance generation of reactive oxygen species (ROS) and induce oxidative stress [75], which is implicated in many degenerative diseases including Alzheimer's disease, Parkinson's disease and cancer. Mouse studies have shown that $\mathrm{TiO}_{2}$ nanoparticles have the potential to convert benign tumor cells to malignant ones through the generation of ROS [76]. Based on the experimental evidence from animal inhalation studies, $\mathrm{TiO}_{2}$ nanoparticles are classified as "possibly carcinogenic to humans" by the International Agency for Research on Cancer [77], and as "occupational carcinogen" by the National Institute for Occupational Safety and Health [78]. However, it is unclear if these results can be extrapolated to human exposure. As a result, implanted titanium is currently not 
classifiable as to its carcinogenicity to humans. Due to its poor water solubility, the metal is not readily excreted in the urine. Nevertheless, blood levels of titanium generally drop with time since implantation $[79,80]$, which could mean that it gradually accumulates in systemic tissues [81]. Failed joint implants were shown to cause profound metal deposition in distant organs. In one patient, particularly extensive dissemination of wear debris lead to the formation of granulomas in the spleen, liver and abdominal lymph nodes, which compromised hepatic function and required medical treatment [17]. The fate of the metal deposits in remote tissues is unknown. It is likely that the particles are retained for many years, and act as a sustained source of metal ions as they undergo gradual dissolution [17]. The clinical implications of chronic low-level exposure to titanium ions are yet to be established.

\section{MEASUREMENT OF TITANIUM IN BIOLOGICAL SAMPLES}

Measurements of serum cobalt and chromium can serve as a biomarker of wear in metal joint implants $[82,83]$. It is now thought that titanium levels could also be used to monitor implant performance [84]. However, it is important that the analytical approach is chosen carefully. While cobalt and chromium levels can be successfully determined by standard quadrupole inductively coupled plasma mass spectrometry (Q ICP-MS), titanium levels cannot, due to a range of polyatomic and isobaric interferences [82]. These interferences can result in spectral overlap when samples with high $\mathrm{Ca}, \mathrm{P}, \mathrm{S}, \mathrm{C}$ and $\mathrm{Cl}$ contents (such as biological samples) are analysed [85], often leading to overestimation of the true analyte concentration [86] (Table 1).

Table 1. The most important spectral interferences affecting titanium measurement in ICPMS.

\begin{tabular}{|l|l|l|}
\hline Isotope & Abundance & Interferences \\
\hline
\end{tabular}




\begin{tabular}{|l|l|l|}
\hline${ }^{46} \mathrm{Ti}$ & 7.99 & $\begin{array}{l}\text { Polyatomic: }{ }^{32} \mathrm{~S}^{14} \mathrm{~N}^{+},{ }^{14} \mathrm{~N}^{16} \mathrm{O}_{2}{ }^{+},{ }^{15} \mathrm{~N}_{2}{ }^{16} \mathrm{O}^{+} \\
\text {Isobaric: }{ }^{46} \mathrm{Ca}\end{array}$ \\
\hline${ }^{47} \mathrm{Ti}$ & 7.32 & $\begin{array}{l}\text { Polyatomic: }{ }^{32} \mathrm{~S}^{14} \mathrm{~N}^{1} \mathrm{H}^{+},{ }^{30} \mathrm{Si}^{16} \mathrm{O}^{1} \mathrm{H}^{+},{ }^{32} \mathrm{~S}^{15} \mathrm{~N}^{+},{ }^{33} \mathrm{~N}^{14} \mathrm{~N}^{+},{ }^{33} \mathrm{~S}^{14} \mathrm{~N}^{+}, \\
{ }^{15} \mathrm{O}_{2}+,{ }^{14} \mathrm{~N}^{16} \mathrm{O}_{2}{ }^{1} \mathrm{H}^{+},{ }^{12} \mathrm{C}^{35} \mathrm{Cl}^{+},{ }^{31} \mathrm{P}^{16} \mathrm{O}^{+}\end{array}$ \\
\hline${ }^{48} \mathrm{Ti}$ & 73.98 & $\begin{array}{l}\text { Polyatomic: }{ }^{32} \mathrm{~S}^{16} \mathrm{O}^{+},{ }^{34} \mathrm{~S}^{14} \mathrm{~N}^{+},{ }^{33} \mathrm{~S}^{15} \mathrm{~N}^{+},{ }^{14} \mathrm{~N}^{16} \mathrm{O}^{18} \mathrm{O}^{+},{ }^{14} \mathrm{~N}^{17} \mathrm{~N}_{2}, \\
{ }^{12} \mathrm{C}_{4}+36{ }^{+} \mathrm{Ar}^{12} \mathrm{C}^{+} \\
\text {Isobaric: }{ }^{48} \mathrm{Ca}\end{array}$ \\
\hline${ }^{49} \mathrm{Ti}$ & 5.46 & $\begin{array}{l}\text { Polyatomic: }{ }^{32} \mathrm{~S}^{17} \mathrm{O}^{+},{ }^{32} \mathrm{~S}^{16} \mathrm{O}^{1} \mathrm{H}^{+},{ }^{35} \mathrm{Cl}^{14} \mathrm{~N}^{+},{ }^{34} \mathrm{~S}^{15} \mathrm{~N}^{+},{ }^{33} \mathrm{~S}^{16} \mathrm{O}^{+}, \\
{ }^{14} \mathrm{~N}^{17} \mathrm{O}_{2}{ }^{1} \mathrm{H}^{+},{ }^{14} \mathrm{~N}^{35} \mathrm{Cl}^{+},{ }^{36} \mathrm{Ar}^{13} \mathrm{C}^{+},{ }^{36} \mathrm{Ar}^{12} \mathrm{C}^{1} \mathrm{H}^{+},{ }^{12} \mathrm{C}^{37} \mathrm{Cl}^{+},{ }^{31} \mathrm{P}^{18} \mathrm{O}^{+}\end{array}$ \\
\hline${ }^{50} \mathrm{Ti}$ & 5.25 & $\begin{array}{l}\text { Polyatomic: }{ }^{32} \mathrm{~S}^{18} \mathrm{O}^{+},{ }^{32} \mathrm{~S}^{17} \mathrm{O}^{1} \mathrm{H}^{+},{ }^{36} \mathrm{Ar}^{14} \mathrm{~N}^{+},{ }^{35} \mathrm{Cl}^{15} \mathrm{~N}^{+},{ }^{36} \mathrm{~S}^{14} \mathrm{~N}^{+}, \\
{ }^{17} \mathrm{O}^{+},{ }^{34} \mathrm{~S}^{16} \mathrm{O}^{+},{ }^{14} \mathrm{H}^{14} \mathrm{~N}^{35} \mathrm{Cl}^{+},{ }^{34} \mathrm{~S}^{15} \mathrm{O}^{1} \mathrm{H}^{+} \\
\text {Isobaric: }{ }^{50} \mathrm{Ca},{ }^{50} \mathrm{~V}\end{array}$ \\
\hline
\end{tabular}

Polyatomic interferences can be reduced through the use of a collision/reaction cell, which transforms the interfering species into ions with a different nominal mass to charge ratio or prevents them from reaching the detector [87]. Another common strategy to minimize spectral interferences is to use a high resolution inductively coupled plasma mass spectrometer (HR ICP-MS), which employs a magnetic and electrostatic sector instead of a quadrupole mass filter, allowing a significant increase in mass resolution. Importantly, HR ICP-MS can remove most polyatomic interferences, but not isobaric interferences. As a result, only the minor isotopes ${ }^{47} \mathrm{Ti}$ and ${ }^{49} \mathrm{Ti}$ can be used for analysis [88]. Nevertheless, the usefulness of HR ICP-MS to detect trace amounts of titanium in blood samples from implanted patients and healthy controls has been demonstrated [79]. Accurate and precise determination of titanium levels in clinical samples can also be achieved with triple quadrupole ICP-MS (ICP-MS/MS). When the instrument was used with a mixture of $\mathrm{NH}_{3}$ and $\mathrm{He}$ as the reaction gas, the detection limit was low enough $\left(3 \mu \mathrm{g} \mathrm{L}^{-1}\right)$ to deal with the very low basal levels of titanium in human serum [85]. The accuracy and precision of HR ICP-MS and ICP-MS/MS come at a price, however, as both machines incur high running costs and require highly trained operators. As a result, they are not widely available in routine clinical laboratories. Inductively coupled plasma optical emission spectroscopy (ICP-OES) could be a more practical and cost-effective solution [89]. The method displayed a low detection limit for the determination of titanium concentration in the serum $\left(0.6 \mu \mathrm{g} \mathrm{L}^{-1}\right)$ [89], 
plasma $\left(1.6 \mu \mathrm{g} \mathrm{L}^{-1}\right)[90]$ and periprosthetic tissue $\left(3.0 \mu \mathrm{g} \mathrm{g}^{-1}\right)$ [91] of patients with MoM hips. However, it was not sensitive enough for whole blood specimens, which usually contain lower levels of titanium than the serum [89].

Regardless of the analytical method used, the risk of sample contamination must always be kept in mind. Given the minute levels of titanium that are being measured, extreme care must be taken to ensure that the samples are collected using blood collection tubes and syringes that are certified for trace metal testing. It is worth noting that, currently, no blood tubes are certified for titanium, but it is reasonable to assume that they are cleaner than standard tubes. Moreover, given the ubiquitous presence of titanium in the air, it is crucial that the samples are contained post-collection. It is still unclear which is the most appropriate sample type to monitor titanium level in the body. Serum samples are preferred by most groups, because the matrix is less complex compared to whole blood. However, analysis of whole blood specimens can lower the limits of detection, increase sensitivity and reliability, and pose less contamination risk than serum [92]. The lack of protocol standardization across laboratories may lead to discrepancies between titanium measurements, and make inter-study comparisons difficult. Koller and co-workers [88] have recently shown that when the same baseline pooled blood samples were analysed by 7 different laboratories, the results differed

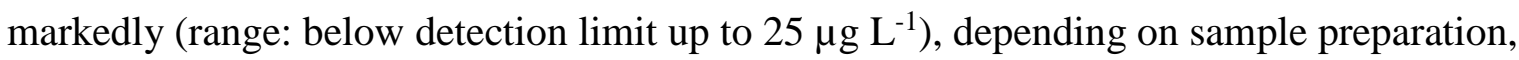
instrument type and analytical approaches used [88]. In light of these results, it would be advisable to use a single laboratory for titanium testing, as values generated from different laboratories may not be directly comparable. In addition, the authors came to the conclusion that a lot of the existing literature on titanium is unreliable because Q ICP-MS was used, and the values are likely overestimated. For this reason, it is imperative that a high resolution instrument is employed.

\subsection{Titanium concentration in unexposed individuals}


Unlike for cobalt and chromium, a biological role for titanium in human body is still uncertain, and no titanium requiring biomolecules have been identified [93]. Nevertheless, 10-20 mg of titanium are found in the human body, making it more common than some of the essential elements [93]. Human exposure to titanium is largely attributable to the ubiquitous presence of $\mathrm{TiO}_{2}$ in the environment, and means that even those without implants will display a certain level of titanium in the blood. $\mathrm{TiO}_{2}$ is an important industrial material used in a range of applications, such as paints, solar panels and catalysts [94]. Due to its brightening and opaquifying properties it features prominently in many personal care products and cosmetics, such as toothpaste, sunscreen and deodorant [95]. In food, $\mathrm{TiO}_{2}$ (referred to as additive E171) serves as white colouring and flavour enhancer that is often added to processed foods and sweets. Exposure to titanium, via ingestion of pigment grade $\mathrm{TiO}_{2}$, is particularly commonplace in westernised populations. In the UK, the median daily adult intake is approximately $2.5 \mathrm{mg}$ (approx. $10^{11}-10^{12}$ particles) [96]. Cases of intravenous exposure are rare and have been mostly reported in drug addicts with a history of injecting crushed-up analgesic tablets coated with titanium pigment [97].

It was traditionally thought that $\mathrm{TiO}_{2}$ particles in the blood must be transformed into their ionic form prior to analysis. This can be achieved with a mixture of concentrated acids. The downside of this method is that the acids themselves contain minute levels of metal ions, which can increase as the acid strips ions from containers used in the sample preparation process [88]. It follows that the benefits of diligent sample preparation using acid digestion must be weighed against the risk of sample contamination. Koller and co-workers [88] suggested that in blood samples carrying $\leq 21.4 \mu \mathrm{g} \mathrm{L}^{-1}$ titanium as $\mathrm{TiO}_{2}$, the particles are efficiently destroyed in the ICP's plasma, meaning that simple dilution is generally fit for purpose, and preferable to digestion.

Early determinations of basal serum titanium, which used neutron activation analysis (NAA), yielded extremely high values $\left(105.7-131 \mu \mathrm{g} \mathrm{L}^{-1}\right)$ [98]. It is now known that NAA, as well as 
most other analytical methods typically used for trace element determination, are not sensitive and/or selective enough to quantify the ultra-trace levels of titanium in body fluids of unexposed individuals [85]. Consequently, values obtained using these techniques are unlikely to reflect those observed in vivo. More recent investigations using HR ICP-MS consistently point to values lower than $1 \mu \mathrm{g} \mathrm{L}^{-1}$ in the whole blood or serum $[15,79,85,99$ 102]. It is thought that detecting blood levels of titanium as low as $0.5 \mu \mathrm{g} \mathrm{L}^{-1}$ should be readily achievable, provided sample contamination and spectral interferences are minimised [88].

\subsection{Titanium concentration in hip and knee replacement patients}

Although most have focused on the toxicity of cobalt and chromium, other studies have also reported issues concerning titanium release from implants [84,103,104]. Since titanium is relatively slowly transported in the body, a modest increase in systemic concentration likely reflects a massive release of titanium into the local joint space, and can potentially serve as a marker for wear or corrosion [105]. The official Medicines and Healthcare products Regulatory Agency (MHRA) guidelines state that whole blood cobalt/chromium concentration exceeding $7 \mu \mathrm{g} \mathrm{L}^{-1}\left(119 \mathrm{nmol} \mathrm{L}^{-1}\right.$ for cobalt or for $134.5 \mathrm{nmol} \mathrm{L}-1$ chromium) suggests potential for adverse soft tissue reactions, and should be re-assessed after a 3-month period [106]. If the levels continue to increase, and/or the imaging studies return abnormal results, revision surgery should be considered. Currently, there are no universally accepted thresholds for titanium that should warrant further investigation.

The 1988 study by Agins and co-workers [10] was one of the first to recognize that titanium release from joint implants might lead to adverse local and systemic tissue responses. The authors noted that titanium prostheses liberated potentially irritating metallic debris into the surrounding tissue, which was enhanced if loosening was present. In line with these results, a three-fold increase in serum titanium was observed in patients with well-functioning 
prostheses containing titanium components, when compared to controls without implants [107]. Loose implants gave rise to even higher titanium levels in the blood [108] and serum [2]. In order to guide investigations for malfunctioning implants, Jacobs and co-workers [84] attempted to set a "normal" cut-off for serum titanium. The authors analysed their database of over 750 serum titanium measurements in patients with and without orthopaedic implants, and concluded that well-functioning, unilateral MoP hip implants should give rise to levels of approximately $4 \mu \mathrm{g} \mathrm{L}^{-1}$ (as measured by graphite furnace atomic absorption spectroscopy). In cases where the value exceeded $8 \mu \mathrm{g} \mathrm{L}^{-1}$, implants were either subject to loosening [14] or accelerated wear due to abrasion [109]. Several other groups have reported serum titanium values of below $8 \mu \mathrm{g} \mathrm{L}^{-1}$ in patients with well-functioning unilateral THA [27,80,100,110112]. Savarino et al, who measured serum titanium in patients with well-fixed implants, calculated that the upper normal reference limit $\left(95^{\text {th }}\right.$ percentile) was $5.13 \mu \mathrm{g} \mathrm{L}^{-1}$ in the medium term (2-7 years post-operation) [111], and $4.5 \mu \mathrm{g} \mathrm{L}^{-1}$ in the long term (10 years postoperation) [112]. Importantly, these were not significantly different from the control grouplikely because of the high detection limit of the instrument $\left(2.91 \mu \mathrm{g} \mathrm{L}^{-1}\right)$. In line with Savarino's findings, Omlor et al [29] showed that median serum titanium values produced by well-functioning implants in the long term (7-13 years) were $3 \mu \mathrm{g} \mathrm{L}^{-1}$ and $6 \mu \mathrm{g} \mathrm{L}^{-1}$ for unilateral and bilateral implants, respectively. Serum titanium values associated with wellfunctioning hip implants rarely exceeded $1 \mu \mathrm{g} \mathrm{L}^{-1}$ at up to 2 years post-operation, when measured by HR ICP-MS [100]. Slightly higher, but comparable, results were obtained by Gofton et al [27]. Lazennec and co-workers [90], who monitored serum titanium levels in patients, up to 11 years post implantation, reported that well-functioning unilateral implants gave rise to values that rarely exceeded $2 \mu \mathrm{g} \mathrm{L}^{-1}$, and that the median values were always below the instrument's detection limit $\left(1.40 \mu \mathrm{g} \mathrm{L}^{-1}\right)$. The highest mean serum levels (up to 14 $\left.\mu \mathrm{g} \mathrm{L}^{-1}\right)$ were reported by Bistolfi et al [113], who investigated metal release from wellfunctioning conventional vs 3D-printed titanium acetabular cups. The authors found that the 
increased porosity of the latter did not result in significantly higher levels of titanium in the serum, at up to 2 years following implantation. When titanium was measured in whole blood, the values ranged from 1 to $9 \mu \mathrm{g} \mathrm{L}^{-1}[79,101,102,114,115]$. Blood/serum titanium levels associated with well-functioning hip implants are summarized in Table 2. 
Table 2. Blood/serum Ti levels associated with different types of well-functioning hip implants.

\begin{tabular}{|c|c|c|c|c|c|}
\hline Implant type & $\begin{array}{l}\text { Analytical } \\
\text { technique }\end{array}$ & $\begin{array}{l}\text { Instrumental DL } \\
\qquad\left(\mu \mathrm{g} \mathrm{L}^{-1}\right)\end{array}$ & Blood Ti $\left(\mu \mathrm{g} \mathrm{L}^{-1}\right)^{\mathrm{a}}$ & Serum Ti $\left(\mu g L^{-1}\right)^{a}$ & Follow up \\
\hline MoP (Ti head, cup and stem) [14] & GF AAS & 2.11 & $\mathrm{n} / \mathrm{a}$ & $5.06 ;<\mathrm{DL}-7.88(\mathrm{n}=9)$ & $47 \mathrm{~m}$ \\
\hline MoP (Ti cup and stem) [14] & GF AAS & 2.11 & $\mathrm{n} / \mathrm{a}$ & $4.42 ;<\mathrm{DL}-7.05(\mathrm{n}=12)$ & $32 \mathrm{~m}$ \\
\hline MoM (uncemented Ti cup) [116] & GF AAS & 2.11 & $\mathrm{n} / \mathrm{a}$ & $\begin{array}{l}1.94 ;<\mathrm{DL}-4.44(\mathrm{n}=20) \\
2.23 ;<\mathrm{DL}-6.55(\mathrm{n}=20)\end{array}$ & $\begin{array}{l}1 \mathrm{y} \\
3 \mathrm{y}\end{array}$ \\
\hline MoM (cemented Ti cup) [116] & GF AAS & 2.11 & $\mathrm{n} / \mathrm{a}$ & $\begin{array}{l}3.15 ;<\mathrm{DL}-7.63(\mathrm{n}=15) \\
2.61 ;<\mathrm{DL}-7.15(\mathrm{n}=15)\end{array}$ & $\begin{array}{l}1 \mathrm{y} \\
3 \mathrm{y}\end{array}$ \\
\hline $\begin{array}{l}\text { MoM (uncemented Ti cup and stem) } \\
{[116]}\end{array}$ & GF AAS & 2.11 & $\mathrm{n} / \mathrm{a}$ & $\begin{array}{l}2.46 ;<D L-5.18(n=20) \\
4.13 ;<D L-11.17(n=20)\end{array}$ & $\begin{array}{l}1 \mathrm{y} \\
3 \mathrm{y}\end{array}$ \\
\hline MoM (Ti cup and stem) [117] & GF AAS & 2.91 & $\mathrm{n} / \mathrm{a}$ & $3.19(\mathrm{n}=15)$ & $18-36 \mathrm{~m}$ \\
\hline MoP (Ti cup and stem) [117] & GF AAS & 2.91 & $\mathrm{n} / \mathrm{a}$ & $\mathrm{n} / \mathrm{d}(\mathrm{n}=13)$ & $18-34 \mathrm{~m}$ \\
\hline CoC (Ti cup and stem) [117] & GF AAS & 2.91 & $\mathrm{n} / \mathrm{a}$ & $3.19(\mathrm{n}=15)$ & $20-30 \mathrm{~m}$ \\
\hline MoP (Ti intermedullary shaft) [102] & HR ICP-MS & 0.1 & $1.45 ; 1.4-1.5(\mathrm{n}=2)$ & $\mathrm{n} / \mathrm{a}$ & $26-38 y$ \\
\hline MoM (Ti intermedullary shaft) [102] & HR ICP-MS & 0.1 & $1.47 ; 1.4-1.5(\mathrm{n}=3)$ & $\mathrm{n} / \mathrm{a}$ & $26-38 y$ \\
\hline
\end{tabular}




\begin{tabular}{|c|c|c|c|c|c|}
\hline MoP (Ti-coated stem, Ti cup) [110] & GF AAS & 2.22 & $\mathrm{n} / \mathrm{a}$ & 2.57; DL-5.72 $(\mathrm{n}=10)$ & $5-7 \mathrm{y}$ \\
\hline CoP (Ti cup) [110] & GF AAS & 2.22 & $\mathrm{n} / \mathrm{a}$ & $3.15 ;$ DL- $8.44(n=10)$ & $9-12.5 \mathrm{y}$ \\
\hline MoM (Ti cup) [110] & GF AAS & 2.22 & $\mathrm{n} / \mathrm{a}$ & 1.87; DL- $5.97(n=10)$ & $5-7 y$ \\
\hline CoC (Ti cup and stem) $[111,112]$ & GF AAS & 2.91 & $\mathrm{n} / \mathrm{a}$ & $\begin{array}{l}\text { 3.44; DL- } 9.68(n=23) \\
3.18 ; \text { DL-6.69 }(n=32)\end{array}$ & $\begin{array}{l}28-78 \mathrm{~m} \\
97-210 \mathrm{~m}\end{array}$ \\
\hline MoM (Ti cup and stem) $[111,112]$ & GF AAS & 2.91 & $\mathrm{n} / \mathrm{a}$ & $\begin{array}{l}3.66 ; \text { DL- } 11.60(n=42) \\
3.43 ; \text { DL- } 7.28(n=16)\end{array}$ & $\begin{array}{l}30-66 \mathrm{~m} \\
106-136 \mathrm{~m}\end{array}$ \\
\hline MoP (Ti cup and stem) [79] & HR ICP-MS & 1.1 & $\begin{array}{l}2.306(\mathrm{n}=11) \\
1.519(\mathrm{n}=11)\end{array}$ & $\begin{array}{l}\mathrm{n} / \mathrm{a} \\
\mathrm{n} / \mathrm{a}\end{array}$ & $\begin{array}{l}14-22 \mathrm{~m} \\
70-106 \mathrm{~m}\end{array}$ \\
\hline $\begin{array}{l}\text { MoM (Ti stem) [90] } \\
\text { Unilateral }\end{array}$ & ICP-OES & 1.4 & $\begin{array}{l}\mathrm{n} / \mathrm{a} \\
\mathrm{n} / \mathrm{a} \\
\mathrm{n} / \mathrm{a} \\
\mathrm{n} / \mathrm{a} \\
\mathrm{n} / \mathrm{a}\end{array}$ & $\begin{array}{l}\mathrm{n} / \mathrm{d}(\mathrm{n}=84) \\
0.70 ; \mathrm{DL}-0.81(\mathrm{n}=84) \\
0.70 ; \mathrm{n} / \mathrm{d}(\mathrm{n}=84) \\
0.70 ; \mathrm{DL}-1.96(\mathrm{n}=84) \\
0.70 ; \mathrm{DL}-1.61(\mathrm{n}=56)\end{array}$ & $\begin{array}{l}1 \mathrm{y} \\
3 \mathrm{y} \\
5 \mathrm{y} \\
7 \mathrm{y} \\
9 \mathrm{y}\end{array}$ \\
\hline
\end{tabular}




\begin{tabular}{|c|c|c|c|c|c|}
\hline Bilateral & & & $\begin{array}{l}\mathrm{n} / \mathrm{a} \\
\mathrm{n} / \mathrm{a} \\
\mathrm{n} / \mathrm{a} \\
\mathrm{n} / \mathrm{a} \\
\mathrm{n} / \mathrm{a}\end{array}$ & $\begin{array}{l}0.70 ; \mathrm{DL}-0.85(\mathrm{n}=25) \\
0.70 ; \mathrm{DL}-1.62(\mathrm{n}=25) \\
0.70 ; \mathrm{DL}-0.80(\mathrm{n}=25) \\
0.70 ; \mathrm{DL}-2.16(\mathrm{n}=25) \\
0.70 ; \mathrm{DL}-1.73(\mathrm{n}=15)\end{array}$ & $\begin{array}{l}1 \mathrm{y} \\
3 \mathrm{y} \\
5 \mathrm{y} \\
7 \mathrm{y} \\
9 \mathrm{y}\end{array}$ \\
\hline MoM (Ti stem and cup) [100] & HR ICP-MS & Not stated $(<0.1)$ & $\begin{array}{l}\mathrm{n} / \mathrm{a} \\
\mathrm{n} / \mathrm{a} \\
\mathrm{n} / \mathrm{a}\end{array}$ & $\begin{array}{l}0.71 ; 0.56-0.92(n=32) \\
0.80 ; 0.62-1.06(n=32) \\
0.85 ; 0.72-1.09(n=32)\end{array}$ & $\begin{array}{l}6 \mathrm{~m} \\
1 \mathrm{y} \\
2 \mathrm{y}\end{array}$ \\
\hline MoP (Ti stem and cup) [100] & HR ICP-MS & Not stated $(<0.1)$ & $\begin{array}{l}\mathrm{n} / \mathrm{a} \\
\mathrm{n} / \mathrm{a} \\
\mathrm{n} / \mathrm{a}\end{array}$ & $\begin{array}{l}0.79 ; 0.61-0.87(n=34) \\
0.78 ; 0.59-1.13(n=34) \\
0.74 ; 0.63-0.98(n=34)\end{array}$ & $\begin{array}{l}6 \mathrm{~m} \\
1 \mathrm{y} \\
2 \mathrm{y}\end{array}$ \\
\hline MoM (Ti stem and cup) [101] & HR ICP-MS & 0.05 & $\begin{array}{l}3.0(\mathrm{n}=9 \text { males }) \\
2.2(\mathrm{n}=6 \text { females })\end{array}$ & $\begin{array}{l}\mathrm{n} / \mathrm{a} \\
\mathrm{n} / \mathrm{a}\end{array}$ & $\begin{array}{l}\mathrm{n} / \mathrm{a} \\
\mathrm{n} / \mathrm{a}\end{array}$ \\
\hline MoM (Ti stem and cup) [114] & HR ICP-MS & Not stated $(<0.1)$ & $\begin{array}{l}3.74 ; 1.40-8.80(n=34) \\
2.75 ; 1.40-4.10(n=33) \\
1.83 ; 0.90-4.60(n=31)\end{array}$ & $\begin{array}{l}\mathrm{n} / \mathrm{a} \\
\mathrm{n} / \mathrm{a} \\
\mathrm{n} / \mathrm{a}\end{array}$ & $\begin{array}{l}3 \mathrm{~m} \\
6 \mathrm{~m} \\
1 \mathrm{y}\end{array}$ \\
\hline
\end{tabular}




\begin{tabular}{|c|c|c|c|c|c|}
\hline & & & $1.30 ; 0.35-2.40(n=24)$ & $\mathrm{n} / \mathrm{a}$ & $2 \mathrm{y}$ \\
\hline $\begin{array}{l}\text { CoP (Ti stem) [29] } \\
\text { Unilateral } \\
\text { Bilateral }\end{array}$ & HR ICP-MS & Not stated $(<0.1)$ & $\begin{array}{l}\mathrm{n} / \mathrm{a} \\
\mathrm{n} / \mathrm{a}\end{array}$ & $\begin{array}{l}2.7 ; 1.1-7(n=6) \\
6.2 ; 2.3-8(n=5)\end{array}$ & $\begin{array}{l}7-13 \mathrm{~m} \\
7-13 \mathrm{~m}\end{array}$ \\
\hline MoM (modular Ti stem) [27] & HR ICP-MS & Not stated $(<0.17)$ & $\begin{array}{l}\mathrm{n} / \mathrm{a} \\
\mathrm{n} / \mathrm{a}\end{array}$ & $\begin{array}{l}2.50 ; 1.50-3.20(n=24) \\
1.50 ; 1.13-3.94(n=24)\end{array}$ & $\begin{array}{l}1 \mathrm{y} \\
2 \mathrm{y}\end{array}$ \\
\hline MoP (modular Ti stem) [27] & HR ICP-MS & Not stated $(<0.17)$ & $\begin{array}{l}\mathrm{n} / \mathrm{a} \\
\mathrm{n} / \mathrm{a}\end{array}$ & $\begin{array}{l}2.54 ; 2.17-3.10(n=23) \\
2.70 ; 2.11-3.25(n=23)\end{array}$ & $\begin{array}{l}1 \mathrm{y} \\
2 \mathrm{y}\end{array}$ \\
\hline MoP (Ti cup and stem) [115] & HR ICP-MS & Not stated $(<0.4)$ & $\begin{array}{l}2.29(\mathrm{n}=10) \\
1.75(\mathrm{n}=10) \\
2.25(\mathrm{n}=10)\end{array}$ & $\begin{array}{l}\mathrm{n} / \mathrm{a} \\
\mathrm{n} / \mathrm{a} \\
\mathrm{n} / \mathrm{a}\end{array}$ & $\begin{array}{l}1 \mathrm{y} \\
2 \mathrm{y} \\
5 \mathrm{y}\end{array}$ \\
\hline CoP (Ti cup and stem) [115] & HR ICP-MS & Not stated $(<0.4)$ & $\begin{array}{l}2.165(n=15) \\
1.359(n=15) \\
2.160(n=15)\end{array}$ & $\begin{array}{l}\mathrm{n} / \mathrm{a} \\
\mathrm{n} / \mathrm{a} \\
\mathrm{n} / \mathrm{a}\end{array}$ & $\begin{array}{l}1 \mathrm{y} \\
2 \mathrm{y} \\
5 \mathrm{y}\end{array}$ \\
\hline CoM (Ti cup and stem) [92] & HR ICP-MS & Not stated $(<2.0)$ & $\mathrm{n} / \mathrm{a}$ & $2.28(\mathrm{n}=74)$ & $25-58 \mathrm{~m}$ \\
\hline
\end{tabular}




\begin{tabular}{|c|c|c|c|c|c|}
\hline $\begin{array}{l}\text { Unknown (3D-printed Ti cup, Ti stem) } \\
\text { [113] }\end{array}$ & $\begin{array}{l}\text { Q ICP-MS } \\
\text { equipped with } \\
\text { collision cell }\end{array}$ & 0.3 & $\begin{array}{l}\mathrm{n} / \mathrm{a} \\
\mathrm{n} / \mathrm{a} \\
\mathrm{n} / \mathrm{a} \\
\mathrm{n} / \mathrm{a}\end{array}$ & $\begin{array}{l}13.60(n=19) \\
12.78(n=19) \\
11.70(n=19) \\
9.43(n=19)\end{array}$ & $\begin{array}{l}3 \mathrm{~m} \\
6 \mathrm{~m} \\
1 \mathrm{y} \\
2 \mathrm{y}\end{array}$ \\
\hline $\begin{array}{l}\text { Unknown (conventional Ti cup, } \mathrm{Ti} \\
\text { stem) [113] }\end{array}$ & $\begin{array}{l}\text { Q ICP-MS } \\
\text { equipped with } \\
\text { collision cell }\end{array}$ & 0.3 & $\begin{array}{l}\mathrm{n} / \mathrm{a} \\
\mathrm{n} / \mathrm{a} \\
\mathrm{n} / \mathrm{a} \\
\mathrm{n} / \mathrm{a}\end{array}$ & $\begin{array}{l}10.29(\mathrm{n}=19) \\
9.05(\mathrm{n}=19) \\
11.34(\mathrm{n}=19) \\
8.90(\mathrm{n}=19)\end{array}$ & $\begin{array}{l}3 \mathrm{~m} \\
6 \mathrm{~m} \\
1 \mathrm{y} \\
2 \mathrm{y}\end{array}$ \\
\hline
\end{tabular}

MoP- metal-on-polyethylene; MoM- metal-on-metal; CoC- ceramic-on-ceramic; CoP- ceramic-on-polyethylene; GF AAS- graphite furnace atomic

absorption spectroscopy; HR ICP-MS- high resolution inductively coupled plasma mass spectrometry; ICP-OES- inductively coupled plasma optical emission spectrometry; Q ICP-MS- quadrupole inductively coupled plasma mass spectrometry; n/d- non-detectable, n/a- not available; DLdetection limit

${ }^{a}$ Results are expressed as "mean/median, range (sample size)" 
Hip replacement patients with loosened titanium components generally exhibited raised serum titanium at the time of implant failure, with the available data ranging from 1.5 to 602 $\mu \mathrm{g} \mathrm{L}^{-1}$. The studies investigating this phenomenon were generally small, involved different implant designs and used a range of analytical techniques to determine the titanium content of blood $[48,102,108]$ or serum $[14,29,90,104]$ of the affected patients, which likely contributed to the observed variability. Cases of broken ceramic liners in $\mathrm{CoC}$ prostheses have also been shown to lead to increased systemic titanium levels. One such case seen at our institution was associated with a blood titanium level of $21.5 \mu \mathrm{g} \mathrm{L}^{-1}$ immediately before revision. The marked elevation was attributed to mechanical abrasion between the femoral head/pieces of the broken ceramic liner and the titanium acetabular shell, as well as impingement between the titanium femoral neck and the edge of the acetabular cup (Figure 1). Interestingly, in the study done by Cooper and co-workers [30], implants revised due to adverse local tissue reaction secondary to corrosion were associated with only mildly raised serum titanium levels (range 1.6- 5.8 $\mu \mathrm{g} \mathrm{L}^{-1}$ ). Cobalt ions, which are more toxic than titanium ions [33], were highly elevated in the serum, and it is likely that they contributed to the adverse reaction.

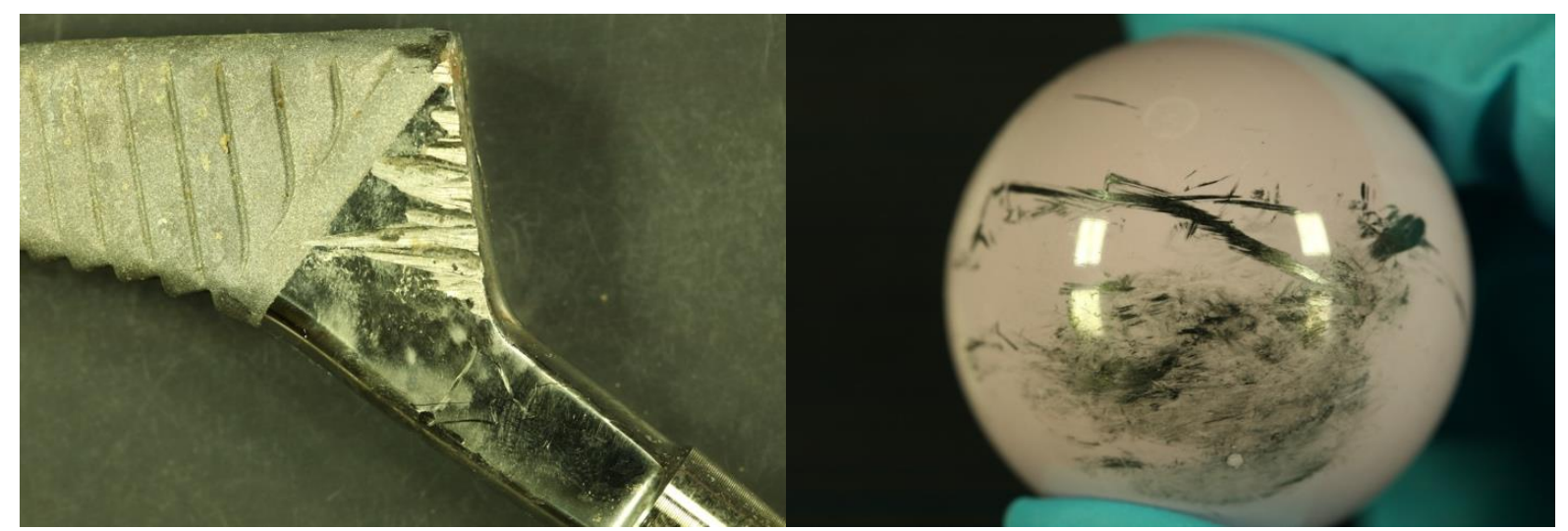

Figure 1. Retrieved components showing a) severe deficits in titanium femoral stem, b) scratch marks on ceramic femoral head. 
Table 3. Blood/serum Ti levels associated with different modes of failure of hip implants.

\begin{tabular}{|c|c|c|c|}
\hline Failure mechanism & Analytical technique & Blood Ti $\left(\mu g L^{-1}\right)^{a}$ & Serum Ti $\left(\mu g L^{-1}\right)^{a}$ \\
\hline $\begin{array}{l}\text { Loosening of a titanium } \\
\text { component }\end{array}$ & $\begin{array}{l}\text { GF AAS } \\
\text { GF AAS } \\
\text { HR ICP-MS } \\
\text { ICP-OES } \\
\text { Not specified } \\
\text { HR ICP-MS }\end{array}$ & $\begin{array}{l}38-602(\mathrm{n}=22)[108] \\
\mathrm{n} / \mathrm{a} \\
1.5-1.8(\mathrm{n}=2)[102] \\
\mathrm{n} / \mathrm{a} \\
\mathrm{n} / \mathrm{a} \\
\mathrm{n} / \mathrm{a}\end{array}$ & $\begin{array}{l}\mathrm{n} / \mathrm{a} \\
<\mathrm{DL}-17.2(\mathrm{n}=21)[14] \\
\mathrm{n} / \mathrm{a} \\
9.1-61(\mathrm{n}=2)[90] \\
15(\mathrm{n}=1)[104] \\
11.3^{\mathrm{b}}(\mathrm{n}=1)[29]\end{array}$ \\
\hline $\begin{array}{l}\text { Breakage of modular neck } \\
\text { related to manufacturing } \\
\text { error }\end{array}$ & HR ICP-MS & $\mathrm{n} / \mathrm{a}$ & $4.5^{\mathrm{b}}(\mathrm{n}=1)[29]$ \\
\hline $\begin{array}{l}\text { Wear, osteolysis and/or } \\
\text { loosening }\end{array}$ & HR ICP-MS & DL-140 $(n=23)[48]$ & $\mathrm{n} / \mathrm{a}$ \\
\hline $\begin{array}{l}\text { Polyethylene wear-through } \\
\text { leading to secondary wear of } \\
\text { titanium acetabular shell }\end{array}$ & Not specified & $\mathrm{n} / \mathrm{a}$ & $280^{\mathrm{b}}(\mathrm{n}=1)[118]$ \\
\hline $\begin{array}{l}\text { Corrosion at the neck-stem } \\
\text { junction }\end{array}$ & Not specified & $\mathrm{n} / \mathrm{a}$ & $1.6-5.8(\mathrm{n}=11)[30]$ \\
\hline $\begin{array}{l}\text { Pseudotumour formation in } \\
\text { local tissue }\end{array}$ & ICP-OES & $\mathrm{n} / \mathrm{a}$ & $30(\mathrm{n}=1)[62]$ \\
\hline $\begin{array}{l}\text { Fracture of ceramic liner } \\
\text { leading to abrasive wear of } \\
\text { titanium cup }\end{array}$ & HR ICP-MS & $21.5^{\mathrm{c}}(\mathrm{n}=1)$ & $\mathrm{n} / \mathrm{a}$ \\
\hline
\end{tabular}

GF AAS- graphite furnace atomic absorption spectroscopy; HR ICP-MS- high resolution inductively coupled plasma mass spectrometry; ICP-OES- inductively coupled plasma optical emission spectrometry; n/a- not available; DL- detection limit 
aResults are expressed as "range (sample size)"; ${ }^{b}$ Sample drawn post-revision of failed implant; ' Unpublished result

In knee replacement patients, failed titanium patellas were shown to lead to particularly large increases in serum titanium. Catastrophic wear of the polyethylene insert, resulting in metalmetal contact between the tibial and femoral components, generated values ranging from 20$716.94 \mu \mathrm{g} \mathrm{L}^{-1}[105,109,119-121]$. Cases with polyethylene wear, but without wear-through, were an order of magnitude lower $[103,120]$.

Table 4. Blood/serum Ti levels associated with different modes of failure of knee implants.

\begin{tabular}{|c|c|c|c|}
\hline Failure mechanism & $\begin{array}{l}\text { Analytical } \\
\text { technique }\end{array}$ & Blood Ti $\left(\mu \mathrm{g} \mathrm{L}^{-1}\right)^{\mathrm{a}}$ & Serum Ti $\left(\mu \mathrm{g} \mathrm{L}^{-1}\right)^{\mathrm{a}}$ \\
\hline $\begin{array}{l}\text { Loosening of a titanium } \\
\text { component }\end{array}$ & GF AAS & $319.6(n=4)[122]$ & $\mathrm{n} / \mathrm{a}$ \\
\hline $\begin{array}{l}\text { Polyethylene wear- } \\
\text { through resulting in } \\
\text { abrasion between tibial } \\
\text { and femoral components }\end{array}$ & $\begin{array}{l}\text { GF AAS } \\
\text { GF AAS } \\
\text { GF AAS } \\
\text { GF AAS } \\
\text { Q ICP-MS } \\
\text { (interference } \\
\text { reduction strategy } \\
\text { not specified) }\end{array}$ & $\begin{array}{l}\text { 68; 9-243(n=7) [105] } \\
\text { n/a } \\
\text { n/a } \\
\text { n/a }\end{array}$ & $\begin{array}{l}108 ; 20-172(\mathrm{n}=7)[105] \\
77(\mathrm{n}=1)[119] \\
135.57 ; 24.12-716.94(\mathrm{n}=8)[109] \\
536.8(\mathrm{n}=1)[121] \\
280 ; 70-425(\mathrm{n}=6)[120]\end{array}$ \\
\hline $\begin{array}{l}\text { Polyethylene wear not } \\
\text { resulting in contact }\end{array}$ & $\begin{array}{l}\text { Q ICP-MS } \\
\text { (interference }\end{array}$ & $\mathrm{n} / \mathrm{a}$ & $12 ; 5-23(n=5)[120]$ \\
\hline
\end{tabular}




\begin{tabular}{|l|l|l|l|}
\hline between tibial and femoral & reduction strategy & & \\
components & not specified $)$ & $\mathrm{n} / \mathrm{a}$ & $65^{\mathrm{b}}(\mathrm{n}=1)[103]$ \\
& Not specified & & \\
\hline
\end{tabular}

GF AAS- graphite furnace atomic absorption spectroscopy; Q ICP-MS- quadrupole

inductively coupled plasma mass spectrometry; n/a- not available

aResults are expressed as "mean/median; range (sample size)"; bSample drawn on day 1 postrevision of failed implant

\section{DISCUSSION AND CONCLUSIONS}

Several authors have called for the determination of blood/serum titanium in patients with titanium-based orthopaedic prostheses, on account of its potential as diagnostic marker of implant performance $[104,119,122,123]$. This is based on the observation that loose implants, as well as those exhibiting wear and polyethylene wear-through, generally liberate higher concentrations of the metal compared to well-functioning implants. Studies have shown that serum titanium levels associated with well-functioning implants can range from less than 1 $\mu \mathrm{g} \mathrm{L}^{-1}$ to approx. $14 \mu \mathrm{g} \mathrm{L}^{-1}$ (Table 2), while poorly functioning prostheses can give rise to values as high as $700 \mu \mathrm{g} \mathrm{L}^{-1}[104,109]$ (Table 3 and 4). Variations in the reported results are likely caused by a combination of factors, including inter-study differences in implant design and stability, number of titanium components implanted [80,89], severity of wear, follow-up time, sample type (whole blood vs serum), analytical approach, as well as patient's environmental exposure to titanium [95], their physical activity and state of health. It is tempting to speculate that if the levels are regularly monitored, one might be able to identify malfunctioning implants before they fail, allowing for a timely revision operation. It might even be possible to use different ranges of serum titanium to distinguish between different modes of implant failure [120], which could further assist the diagnosis. However, in order to do this, an official threshold value that would guide investigations for failing 
implants is needed. Unfortunately, the scarcity of studies that probe titanium levels in patients with orthopaedic implants means that clear cut-off values are difficult to establish. The current Mayo Clinic Laboratory guidelines state that a "modest increase (1.0-3.0 $\left.\mu \mathrm{g} \mathrm{L}^{-1}\right)$ in serum titanium concentration is evident with a prosthetic device in good condition, while serum concentrations $>10 \mu \mathrm{g} \mathrm{L}^{-1}$ in a patient with titanium-based implant suggest prosthesis wear". These values are based on the 1998 works by Jacobs [116] and Liu [122]. The former study, employing 55 patients with 3 different types of titanium-based hip implants, used graphite furnace atomic absorption spectroscopy (GF AAS) to quantify serum titanium levels associated with well-functioning implants. The latter study, employing only 9 patients with titanium-based knee implants, used GF AAS to measure the whole blood titanium concentrations corresponding to stable (5 patients) and loosened (4 patients) prostheses. In addition to small sample size, both studies used analytical instruments with detection limits that are currently considered not low enough for accurate determination of titanium in biological samples (2.11 and $5 \mu \mathrm{g} \mathrm{L}^{-1}$, respectively). Updated guidelines, derived from HR ICP-MS or ICP-MS/MS analyses, are warranted.

Future studies investigating titanium levels associated with well-functioning implants should divide the participants according to the number of titanium components implanted. In each cohort, the patients should be matched for age, activity level and follow up time, and they should ideally be operated on by the same surgical team. Titanium is poorly soluble and tends to accumulate in organ tissue, such as the liver and spleen. However, a small fraction of the liberated titanium is still excreted in the urine. For this reason, it might be important that the participants display normal renal function (impaired excretion processes might result in increased retention of titanium in the body, leading to skewed results). The blood/serum specimens ought to be collected using apparatus certified for trace metal testing, with a technique that minimizes contamination. It is imperative that the specimens are then sent to the same laboratory and analysed according to a standardised protocol, preferably on an HR 
ICP-MS or ICP-MS/MS instrument, as these offer the most sensitive and accurate means of measuring titanium in biological samples. In the case of poorly functioning implants, the study should divide the participants according to the specific mode of failure so that titanium levels corresponding each mechanism could be estimated.

Due to the scarcity of large studies, and differences in analytical approaches employed by different laboratories, meaningful inter-study comparisons and reliable conclusions regarding "normal" and "abnormal" titanium levels in patients with orthopaedic implants are difficult to draw. The matter is further complicated by the multifactorial nature of implant degradation, which implicates a number of implant, surgeon and patient influences- some of which impossible to control for. Until more data becomes available, diagnosis of symptomatic patients should be based on radiographic evidence combined with blood/serum metal ion levels. In patients with prostheses containing cobalt-chromium components, as well as titanium ones, measurement of all three metals should be requested. Even though cobalt is considered more toxic than titanium, adverse tissue reactions can develop in the absence of CoCr alloy components [64], which underscores the importance of titanium measurements to monitor the risk of local toxicity. This is particularly important in patients with a known sensitivity to titanium.

\section{REFERENCES}

[1] O. Posada, R. Tate, R.M. Meek, M. Grant, In Vitro Analyses of the Toxicity, Immunological, and Gene Expression Effects of Cobalt-Chromium Alloy Wear Debris and Co Ions Derived from Metal-on-Metal Hip Implants, Lubricants. 3 (2015) 539568. doi:10.3390/lubricants3030539.

[2] J. Jacobs, Release and excretion of metal in patients who have total hip replacement component made of titanium-base alloy, J. Bone Jt. Surg. 74-A (1992) 1430-1432.

[3] L. Hjalmarsson, J.I. Smedberg, A. Wennerberg, Material degradation in implantretained cobalt-chrome and titanium frameworks, J. Oral Rehabil. 38 (2011) 61-71. doi:10.1111/j.1365-2842.2010.02127.x.

[4] E. Lukina, A. Laka, M. Kollerov, M. Sampiev, P. Mason, P. Wagstaff, H. Noordeen, W.W. Yoon, G. Blunn, Metal concentrations in the blood and tissues after implantation of titanium growth guidance sliding instrumentation, Spine J. 16 (2016) 380-388. doi:10.1016/j.spinee.2015.11.040. 
[5] G. Honari, S.G. Ellis, B.L. Wilkoff, M.A. Aronica, L.G. Svensson, J.S. Taylor, Hypersensitivity reactions associated with endovascular devices, Contact Dermatitis. 59 (2008) 7-22. doi:10.1111/j.1600-0536.2008.01351.x.

[6] R. Solar, Corrosion Resistance of Titanium Surgical Innplant Alloys : A Review, (1979) 259-273. doi:10.1520/STP35949S.

[7] R.J. Solar, S.R. Pollack, E. Korostoff, In vitro corrosion testing of titanium surgical implant alloys: An approach to understanding titanium release from implants, J.

Biomed. Mater. Res. 13 (1979) 217-250. doi:10.1002/jbm.820130206.

[8] P. Hallam, F. Haddad, J. Cobb, Pain in the well-fixed, aseptic titanium hip replacement, J. Bone Jt. Surg. 86-B (2004) 27-30. doi:10.1302/0301620X.87B5.16342.

[9] A. Ferguson, Jun, P. Laing, E. Hodge, The ionization of metal implants in living tissues, J. Bone Jt. Surg. 42 (1960) 77-90.

[10] H. Agins, N. Alcock, M. Bansal, E. Salvati, P. Wilson, P. Pellicci, P. Bullough, Metallic Wear in Failed Titanium-Alloy Total Hip Replacements, J. Bone Jt. Surg. 70A (1988) 347-376.

[11] P.G. Laing, A.B. Ferguson, E.S. Hodge, Tissue reaction in rabbit muscle exposed to metallic implants, J. Biomed. Mater. Res. 1 (1967) 135-149. doi:10.1002/jbm.820010113.

[12] G. Meachim, D.F. Williams, Changes in nonosseous tissue adjacent to titanium implants, J. Biomed. Mater. Res. 7 (1973) 555-572. doi:10.1002/jbm.820070607.

[13] S. Ichinose, T. Muneta, I. Sekiya, S. Itoh, H. Aoki, M. Tagami, The study of metal ion release and cytotoxicity in Co-Cr-Mo and Ti-Al-V alloy in total knee prosthesis Scanning electron microscopic observation, J. Mater. Sci. Mater. Med. 14 (2003) 7986. doi:10.1023/A:1021557605458.

[14] J. Jacobs, A. Skipor, J. Black, R. Urban, J. Galante, Release and excretion of metal in patients who have a total hip-replacement component made of titanium-base alloy, J. Bone Jt. Surg. 73-A (1991) 1475-1486.

[15] Y. Nuevo-Ordonez, M. Montes-Bayyon, E. Blanco-Gonzalez, J. Paz-Aparicio, J.D. Raimundez, J.M. Tejerina, M.A. Pena, A. Sanz-Medel, Titanium release in serum of patients with different bone fixation implants and its interaction with serum biomolecules at physiological levels, Anal. Bioanal. Chem. 401 (2011) 2747-2754. doi:10.1007/s00216-011-5232-8.

[16] A. Sarmiento-González, J.R. Encinar, J.M. Marchante-Gayón, A. Sanz-Medel, Titanium levels in the organs and blood of rats with a titanium implant, in the absence of wear, as determined by double-focusing ICP-MS, Anal. Bioanal. Chem. 393 (2009) 335-343. doi:10.1007/s00216-008-2449-2.

[17] R.M. Urban, J.J. Jacobs, M.J. Tomlinson, J. Gavrilovic, J. Black, M. Peoc'h, Dissemination of wear particles to the liver, spleen, and abdominal lymph nodes of patients with hip or knee replacement, J. Bone Joint Surg. Am. 82-A (2000) 457-476. http://www.ncbi.nlm.nih.gov/pubmed/10761937.

[18] J.L. Woodman, J.J. Jacobs, J.O. Galante, R.M. Urban, Metal ion release from titaniumbased prosthetic segmental replacements of long bones in baboons: A long term study, J. Orthop. Res. 1 (1983) 421-430. doi:10.1002/jor.1100010411.

[19] I. Swiatkowska, J.F.W. Mosselmans, T. Geraki, C.C. Wyles, J.J. Maleszewski, J. Henckel, B. Sampson, D.B. Potter, I. Osman, R.T. Trousdale, A.J. Hart, Synchrotron analysis of human organ tissue exposed to implant material, J. Trace Elem. Med. Biol. 46 (2018) 128-137. doi:10.1016/j.jtemb.2017.12.007.

[20] C.A. Moran, F.G. Mullick, K.G. Ishak, F.B. Johnson, W.B. Hummer, Identification of titanium in human tissues: Probable role in pathologic processes, Hum. Pathol. 22 (1991) 450-454. doi:10.1016/0046-8177(91)90130-H. 
[21] Z. Chen, Y. Wang, L. Zhuo, S. Chen, L. Zhao, X. Luan, H. Wang, G. Jia, Effect of titanium dioxide nanoparticles on the cardiovascular system after oral administration, Toxicol. Lett. 239 (2015) 123-130. doi:10.1016/j.toxlet.2015.09.013.

[22] L. Sheng, X. Wang, X. Sang, Y. Ze, X. Zhao, D. Liu, S. Gui, Q. Sun, J. Cheng, Z. Cheng, R. Hu, L. Wang, F. Hong, Cardiac oxidative damage in mice following exposure to nanoparticulate titanium dioxide, J. Biomed. Mater. Res. - Part A. 101 (2013) 3238-3246. doi:10.1002/jbm.a.34634.

[23] H. Liu, L. Ma, J. Zhao, J. Liu, J. Yan, J. Ruan, F. Hong, Biochemical toxicity of nanoanatase TiO2 particles in mice, Biol. Trace Elem. Res. 129 (2009) 170-180. doi:10.1007/s12011-008-8285-6.

[24] J. Chen, X. Dong, J. Zhao, G. Tang, In vivo acute toxicity of titanium dioxide nanoparticles to mice after intraperitioneal injection, J. Appl. Toxicol. 29 (2009) 330337. doi:10.1002/jat.1414.

[25] N. Li, Y. Duan, M. Hong, L. Zheng, M. Fei, X. Zhao, J. Wang, Y. Cui, H. Liu, J. Cai, S. Gong, H. Wang, F. Hong, Spleen injury and apoptotic pathway in mice caused by titanium dioxide nanoparticules, Toxicol. Lett. 195 (2010) 161-168. doi:10.1016/j.toxlet.2010.03.1116.

[26] F. Findik, Titanium Based Biomaterials, Curr. Trends Biomed. Eng. Biosci. 7 (2017) 1-3. doi:10.19080/CTBEB.2017.07.555714.

[27] W. Gofton, P.E. Beaule, Serum Metal Ions with a Titanium Modular Neck Total Hip Replacement System, J. Arthroplasty. 30 (2015) 1781-1786. doi:10.1016/j.arth.2015.04.040.

[28] M. Meftah, A.M. Haleem, M.B. Burn, K.M. Smith, S.J. Incavo, Early corrosionrelated failure of the rejuvenate modular total hip replacement., J. Bone Joint Surg. Am. 96 (2014) 481-7. doi:10.2106/JBJS.M.00979.

[29] G.W. Omlor, J.P. Kretzer, J. Reinders, M.R. Streit, T. Bruckner, T. Gotterbarm, P.R. Aldinger, C. Merle, In vivo serum titanium ion levels following modular neck total hip arthroplasty-10 year results in 67 patients, Acta Biomater. 9 (2013) 6278-6282. doi:10.1016/j.actbio.2012.12.001.

[30] H.J. Cooper, R.M. Urban, R.L. Wixson, R.M. Meneghini, J.J. Jacobs, Adverse local tissue reaction arising from corrosion at the femoral neck-body junction in a dual-taper stem with a cobalt-chromium modular neck., J. Bone Joint Surg. Am. 95 (2013) 86572. doi:10.2106/JBJS.L.01042.

[31] J.J. Jacobs, H.J. Cooper, R.M. Urban, R.L. Wixson, C.J. Della Valle, What Do We Know About Taper Corrosion in Total Hip Arthroplasty?, J. Arthroplasty. 29 (2014) 668-669. doi:10.1016/j.arth.2014.02.014.

[32] M. Kiran, K.G. Makridis, C. Armstrong, B. Kapoor, G. Kumar, V. Peter, A Randomized Controlled Trial Comparing Modular and Nonmodular Neck Versions of a Titanium Stem, J. Arthroplasty. (2018) 1-4. doi:10.1016/j.arth.2018.09.039.

[33] A. Dalal, V. Pawar, K. McAllister, C. Weaver, N.J. Hallab, Orthopedic implant cobaltalloy particles produce greater toxicity and inflammatory cytokines than titanium alloy and zirconium alloy-based particles in vitro, in human osteoblasts, fibroblasts, and macrophages, J. Biomed. Mater. Res. - Part A. 100 A (2012) 2147-2158. doi:10.1002/jbm.a.34122.

[34] N. Cobelli, B. Scharf, G.M. Crisi, J. Hardin, L. Santambrogio, Mediators of the inflammatory response to joint replacement devices, Nat. Rev. Rheumatol. 7 (2011) 600-608. doi:10.1038/nrrheum.2011.128.

[35] D. Cadosch, E. Chan, O.P. Gautschi, L. Filgueira, Metal is not inert: Role of metal ions released by biocorrosion in aseptic loosening - Current concepts, J. Biomed. Mater. Res. - Part A. 91 (2009) 1252-1262. doi:10.1002/jbm.a.32625.

[36] D.R. Bijukumar, A. Segu, J.C.M. Souza, X.J. Li, M. Barba, L.G. Mercuri, J. J. Jacobs, 
M.T. Mathew, Systemic and local toxicity of metal debris released from hip prostheses: A review of experimental approaches, Nanomedicine Nanotechnology, Biol. Med. 14 (2018) 951-963. doi:10.1016/j.nano.2018.01.001.

[37] S.D. Rogers, D.W. Howie, S.E. Graves, M.J. Pearcy, D.R. Haynes, In Vitro Human Monocyte Response To Wear Particles Of Titanium Alloy Containing Vanadium Or Niobium, J. Bone Jt. Surg. 79 (1997) 311-315. doi:10.1302/0301-620X.79B2.7192.

[38] L.K. Braydich-Stolle, N.M. Schaeublin, R.C. Murdock, J. Jiang, P. Biswas, J.J. Schlager, S.M. Hussain, Crystal structure mediates mode of cell death in TiO2nanotoxicity, J. Nanoparticle Res. 11 (2009) 1361-1374. doi:10.1007/s11051008-9523-8.

[39] C.M. Sayes, R. Wahi, P.A. Kurian, Y. Liu, J.L. West, K.D. Ausman, D.B. Warheit, V.L. Colvin, Correlating nanoscale titania structure with toxicity: A cytotoxicity and inflammatory response study with human dermal fibroblasts and human lung epithelial cells, Toxicol. Sci. 92 (2006) 174-185. doi:10.1093/toxsci/kfj197.

[40] J. Zhang, W. Song, J. Guo, J. Zhang, Z. Sun, L. Li, F. Ding, M. Gao, Cytotoxicity of different sized $\mathrm{TiO} 2$ nanoparticles in mouse macrophages, Toxicol. Ind. Health. 29 (2012) 523-533. doi:10.1177/0748233712442708.

[41] M.G. Choi, H.S. Koh, D. Kluess, D. O’Connor, A. Mathur, G.A. Truskey, J. Rubin, D.X.F. Zhou, K.-L.P. Sung, Effects of titanium particle size on osteoblast functions in vitro and in vivo, Proc. Natl. Acad. Sci. 102 (2005) 4578-4583. doi:10.1073/pnas.0500693102.

[42] D.T. O'Connor, M.G. Choi, S.Y. Kwon, K.L. Paul Sung, New insight into the mechanism of hip prosthesis loosening: Effect of titanium debris size on osteoblast function, J. Orthop. Res. 22 (2004) 229-236. doi:10.1016/S0736-0266(03)00167-0.

[43] Z. Xia, B.F. Ricciardi, Z. Liu, C. von Ruhland, M. Ward, A. Lord, L. Hughes, S.R. Goldring, E. Purdue, D. Murray, G. Perino, Nano-analyses of wear particles from metal-on-metal and non-metal-on-metal dual modular neck hip arthroplasty, Nanomedicine Nanotechnology, Biol. Med. 13 (2017) 1205-1217. doi:10.1016/j.nano.2016.11.003.

[44] J. Zhao, L. Bowman, X. Zhang, V. Vallyathan, S.H. Young, V. Castranova, M. Ding, Titanium dioxide (tiO2) nanoparticles induce JB6 cell apoptosis through activation of the caspase-8/bid and mitochondrial pathways, J. Toxicol. Environ. Heal. - Part A Curr. Issues. 72 (2009) 1141-1149. doi:10.1080/15287390903091764.

[45] G. Oberdörster, Pulmonary effects of inhaled ultrafine particles, Int. Arch. Occup. Environ. Health. 74 (2001) 1-8. doi:10.1007/s004200000185.

[46] H. Shi, R. Magaye, V. Castranova, J. Zhao, Titanium dioxide nanoparticles: a review of current toxicological data, Cosm. Res. 10 (2013) 1-33. doi:10.1186/1743-8977-1015.

[47] B.F. Shahgaldi, F.W. Heatley, A. Dewar, B. Corrin, In vivo corrosion of cobaltchromium and titanium wear particles., J. Bone Joint Surg. Br. 77 (1995) 962-6. http://www.ncbi.nlm.nih.gov/pubmed/7593115.

[48] S. Grosse, H.K. Haugland, P. Lilleng, P. Ellison, G. Hallan, P. Johan, Wear particles and ions from cemented and uncemented titanium-based hip prostheses - A histological and chemical analysis of retrieval material, J. Biomed. Mater. Res. Part B Appl. Biomater. (2014) 709-717. doi:10.1002/jbm.b.33243.

[49] J. Jacobs, R. Urban, J. Wall, J. Black, J. Reid, L. Veneman, Unusual Foreign-Body Reaction to a Failed Total Knee Replacement: Simulation of a Sarcoma Clinically and a Sarcoid Histologically, J. Bone Jt. Surg. 77-A (1995) 444-451.

[50] J.C.K. Lai, M.B. Lai, S. Jandhyam, V. V. Dukhande, A. Bhushan, C.K. Daniels, S.W. Leung, Exposure to titanium dioxide and other metallic oxide nanoparticles induces cytotoxicity on human neural cells and fibroblasts, Int. J. Nanomedicine. 3 (2008) 
533-545. doi:10.2147/IJN.S3234.

[51] C. Jin, B. Zhu, X. Wang, Q. Lu, Cytotoxicity of Titanium Dioxide Nanoparticles in Mouse Fibroblast Cells Cytotoxicity of Titanium Dioxide Nanoparticles in Mouse Fibroblast, Chem. Res. Toxicol. 21 (2008) 1871-1877. doi:10.1021/tx800179f.

[52] M. Goutam, C. Giriyapura, S. Mishra, S. Gupta, Titanium allergy: A literature review, Indian J. Dermatol. 59 (2014) 630. doi:10.4103/0019-5154.143526.

[53] K. Magone, D. Luckenbill, T. Goswami, Metal ions as inflammatory initiators of osteolysis, Arch. Orthop. Trauma Surg. 135 (2015) 683-695. doi:10.1007/s00402-0152196-8.

[54] J.J. Wang, B.J.S. Sanderson, H. Wang, Cyto- and genotoxicity of ultrafine TiO2 particles in cultured human lymphoblastoid cells, Mutat. Res. 628 (2007) 99-106. doi:10.1016/j.mrgentox.2006.12.003.

[55] E. Chan, D. Cadosch, O.P. Gautschi, K. Sprengel, L. Filgueira, Influence of metal ions on human lymphocytes and the generation of titanium-specific T-lymphocytes, J. Appl. Biomater. Biomech. 9 (2011) 137-143. doi:10.5301/JABB.2011.8567.

[56] J.J. Yao, E.A. Lewallen, W.H. Trousdale, W. Xu, R. Thaler, C.G. Salib, N. Reina, M.P. Abdel, D.G. Lewallen, A.J. Van Wijnen, Local Cellular Responses to Titanium Dioxide from Orthopedic Implants, BioResearch. 6 (2017) 94-103. doi:10.1089/biores.2017.0017.

[57] E.A. Fritz, J.J. Jacobs, T.T. Glant, K.A. Roebuck, Chemokine IL-8 induction by particulate wear debris in osteoblasts is mediated by NF- j B, 23 (2005) 1249-1257. doi:10.1016/j.orthres.2005.03.013.

[58] K.A. Roebuck, C. Vermes, L.R. Carpenter, E.A. Fritz, R. Narayanan, T.T. Glant, Down-Regulation of Procollagen alpha1[I] Messenger RNA by Titanium Particles Correlates with Nuclear Factor kB( NF-kB). Activation and Increased Rel A and NFkB1 Binding to the Collagen Promoter, J. Bone Miner. Res. 16 (2001) 501-510.

[59] H. Warashina, S. Sakano, S. Kitamura, K.I. Yamauchi, J. Yamaguchi, N. Ishiguro, Y. Hasegawa, Biological reaction to alumina, zirconia, titanium and polyethylene particles implanted onto murine calvaria, Biomaterials. 24 (2003) 3655-3661. doi:10.1016/S0142-9612(03)00120-0.

[60] H. Zreiqat, T.N. Crotti, C.R. Howlett, M. Capone, B. Markovic, D.R. Haynes, Prosthetic particles modify the expression of bone-related proteins by human osteoblastic cells in vitro, Biomaterials. 24 (2003) 337-346. doi:10.1016/S01429612(02)00324-1.

[61] A. Lombardi, Aseptic loosening in total hip arthroplasty secondary to osteolysis induced by wear debris from titanium-alloy modular femoral heads, J. Bone Jt. Surg. 71-A (1989) 1337-1342.

[62] M. Sakamoto, H. Watanabe, H. Higashi, H. Kubosawa, Pseudotumor Caused by Titanium Particles From a Total Hip Prosthesis, Orthopedics. 39 (2016) e162-e165. doi:10.3928/01477447-20151218-12.

[63] A. Hsu, C. Gross, Br, Pseudotumor from modular neck corrosion after ceramic-onpolyethylene total hip arthroplasty, Am. J. Orthop. 41 (2012) 422-426.

[64] E.J. Mcpherson, M. V Dipane, S.M. Sherif, Massive Pseudotumor in a $28 \mathrm{~mm}$ Ceramic- Polyethylene Revision THA: A Case Report, JISRF Reconstr. Rev. 4 (2014) 11-17. doi:10.15438/rr.v4i1.53.

[65] C.P. Case, V.G. Langkamer, C. James, M.R. Palmer, A.J. Kemp, P.F. Heap, L. Solomon, Widespread dissemination of metal debris from implants, J. Bone Jt. Surgery. 76 (1994) 701-12. http://www.ncbi.nlm.nih.gov/pubmed/8083255.

[66] A.D. Tinoco, E. V Eames, A.M. Valentine, Reconsideration of Serum Ti (IV) Transport: Albumin and Transferrin Trafficking of Ti(IV) and Its Complexes, JACS. 130 (2008) 2262-2270. 
[67] M. Golasik, M. Herman, W. Piekoszewski, Toxicological aspects of soluble titaniuma review of in vitro and in vivo studies, Metallomics. 8 (2016) 1227-1242. doi:10.1039/C6MT00110F.

[68] M. Saxena, S.A. Loza-Rosas, K. Gaur, S. Sharma, S.C. Pérez Otero, A.D. Tinoco, Exploring titanium(IV) chemical proximity to iron(III) to elucidate a function for Ti(IV) in the human body, Coord. Chem. Rev. 363 (2018) 109-125. doi:10.1016/j.ccr.2018.03.006.

[69] J.J. Yao, E.A. Lewallen, W.H. Trousdale, W. Xu, R. Thaler, C.G. Salib, N. Reina, M.P. Abdel, D.G. Lewallen, A.J. van Wijnen, Local Cellular Responses to Titanium Dioxide from Orthopedic Implants, Biores. Open Access. 6 (2017) 94-103. doi:10.1089/biores.2017.0017.

[70] F. Hong, N. Wu, X. Zhao, Y. Tian, Y. Zhou, T. Chen, Y. Zhai, L. Ji, Titanium dioxide nanoparticle-induced dysfunction of cardiac hemodynamics is involved in cardiac inflammation in mice, J. Biomed. Mater. Res. - Part A. 104 (2016) 2917-2927. doi:10.1002/jbm.a.35831.

[71] H.R.H. Mohamed, N.A. Hussien, Genotoxicity Studies of Titanium Dioxide Nanoparticles (TiO2NPs) in the Brain of Mice, Scientifica (Cairo). 2016 (2016) 1-7. doi:10.1155/2016/6710840.

[72] R. Hu, X. Gong, Y. Duan, N. Li, Y. Che, Y. Cui, M. Zhou, C. Liu, H. Wang, F. Hong, Neurotoxicological effects and the impairment of spatial recognition memory in mice caused by exposure to TiO2 nanoparticles, Biomaterials. 31 (2010) 8043-8050. doi:10.1016/j.biomaterials.2010.07.011.

[73] A. Mohammadipour, M. Hosseini, A. Fazel, H. Haghir, H. Rafatpanah, M. Pourganji, A.E. Bideskan, The effects of exposure to titanium dioxide nanoparticles during lactation period on learning and memory of rat offspring, Toxicol. Ind. Health. 32 (2016) 221-228. doi:10.1177/0748233713498440.

[74] N. Coen, M.A. Kadhim, E.G. Wright, C.P. Case, C.E. Mothersill, Particulate debris from a titanium metal prosthesis induces genomic instability in primary human fibroblast cells, Br. J. Cancer. 88 (2003) 548-552. doi:10.1038/sj.bjc.6600758.

[75] P.P. Fu, Q. Xia, H.M. Hwang, P.C. Ray, H. Yu, Mechanisms of nanotoxicity: Generation of reactive oxygen species, J. Food Drug Anal. 22 (2014) 64-75. doi:10.1016/j.jfda.2014.01.005.

[76] K. Onuma, Y. Sato, S. Ogawara, N. Shirasawa, M. Kobayashi, J. Yoshitake, T. Yoshimura, M. Iigo, J. Fujii, F. Okada, Nano-scaled particles of titanium dioxide convert benign mouse fibrosarcoma cells into aggressive tumor cells, Am. J. Pathol. 175 (2009) 2171-2183. doi:10.2353/ajpath.2009.080900.

[77] IARC. Carbon black, titanium dioxide, and talc. IARC monographs on the evaluation of carcinogenic risks to humans, vol. 93. International Agency for Research on Cancer: Lyon, France, 2006, (n.d.).

[78] NIOSH. Occupational Exposure to Titanium Dioxide. Department Of Health And Human Services, Centers for Disease Control and Prevention, National Institute for Occupational Safety and Health 2011, (n.d.).

[79] A. Sarmiento-González, J.M. Marchante-Gayón, J.M. Tejerina-Lobo, J. Paz-Jiménez, A. Sanz-Medel, High-resolution ICP-MS determination of Ti, V, Cr, Co, Ni, and Mo in human blood and urine of patients implanted with a hip or knee prosthesis, Anal. Bioanal. Chem. 391 (2008) 2583-2589. doi:10.1007/s00216-008-2188-4.

[80] B.R. Levine, A.R. Hsu, A.K. Skipor, N.J. Hallab, W.G. Paprosky, J.O. Galante, J.J. Jacobs, Ten-Year Outcome of Serum Metal Ion Levels After Primary Total Hip Arthroplasty, J. Bone Jt. Surg. 95 (2013) 512-518. doi:10.2106/JBJS.L.00471.

[81] E. Fabian, R. Landsiedel, L. Ma-Hock, K. Wiench, W. Wohlleben, B. Van Ravenzwaay, Tissue distribution and toxicity of intravenously administered titanium 
dioxide nanoparticles in rats, Arch. Toxicol. 82 (2008) 151-157. doi:10.1007/s00204007-0253-y.

[82] B. Sampson, A. Hart, Clinical usefulness of blood metal measurements to assess the failure of metal-on-metal hip implants., Ann. Clin. Biochem. 49 (2012) 118-31. doi:10.1258/acb.2011.011141.

[83] K. De Smet, R. De Haan, A. Calistri, P.A. Campbell, E. Ebramzadeh, C. Pattyn, H.S. Gill, Metal-on-Metal Hip Resurfacing Metal Ion Measurement as a Diagnostic Tool to Identify Problems with Metal Ion Measurement as a Diagnostic Tool to Identify Problems with Metal-on-Metal Hip Resurfacing, J Bone Jt. Surg Am. (2008) 202-208. doi:10.2106/JBJS.H.00672.

[84] J.J. Jacobs, A.K. Skipor, P.A. Campbell, N.J. Hallab, R.M. Urban, H.C. Amstutz, Can metal levels be used to monitor metal-on-metal hip arthroplasties?, J. Arthroplasty. 19 (2004) 59-65. doi:10.1016/j.arth.2004.09.019.

[85] L. Balcaen, E. Bolea-Fernandez, M. Resano, F. Vanhaecke, Accurate determination of ultra-trace levels of Ti in blood serum using ICP-MS/MS, Anal. Chim. Acta. 809 (2014) 1-8. doi:10.1016/j.aca.2013.10.017.

[86] S. McGarry, S.J. Morgan, R.M. Grosskreuz, A.E. Williams, W.R. Smith, Serum titanium levels in individuals undergoing intramedullary femoral nailing with a titanium implant, J. Trauma - Inj. Infect. Crit. Care. 64 (2008) 430-433. doi:10.1097/01.ta.0000240445.20220.54.

[87] A. Sarmiento-Gonzalez, J.M. Marchante-Gayon, J. Tejerina-Lobo, J. Paz-Jimenez, A. Sanz-Medel, ICP-MS multielemental determination of metals potentially released from dental implants and articular prostheses in human biological fluids, Anal. Bioanal. Chem. 382 (2005) 1001-1009. doi:10.1007/s00216-005-3165-9.

[88] D. Koller, P. Bramhall, J. Devoy, H. Goenaga-Infante, C.F. Harrington, E. Leese, J. Morton, S. Nuñez, J. Rogers, B. Sampson, J.J. Powell, Analysis of soluble or titanium dioxide derived titanium levels in human whole blood: consensus from an interlaboratory comparison, Analyst. (2018). doi:10.1039/C8AN00824H.

[89] C.F. Harrington, C. Mckibbin, M. Rahanu, D. Langton, Titanium in hip replacement patients by Inductively Coupled Plasma Optical Emission Spectroscopy (ICP-OES), Ann. Clin. Biochem. 0 (2016) 1-8. doi:10.1177/0004563216662292.

[90] J.Y. Lazennec, P. Boyer, J. Poupon, M.A. Rousseau, C. Roy, P. Ravaud, Y. Catonné, Outcome and serum ion determination up to 11 years after implantation of a cemented metal-on-metal hip prosthesis, Acta Orthop. 80 (2009) 168-173. doi:10.3109/17453670902947408.

[91] L. Lehtovirta, A. Reito, J. Parkkinen, S. Pera, A. Eskelinen, Association between periprosthetic tissue metal content, whole blood and synovial fluid metal ion levels and histopathological findings in patients with failed metal-on-metal hip replacement, PLoS One. 13 (2018) 1-13.

[92] Z. Yi, Z. Bo, S. Bin, Y. Jing, Z. Zongke, P. Fuxing, Clinical Results and Metal Ion Levels After Ceramic-on-Metal Total Hip Arthroplasty: A Mean 50-Month Prospective Single-Center Study, J. Arthroplasty. 31 (2016) 438-441. doi:10.1016/j.arth.2015.09.034.

[93] K.M. Buettner, A.M. Valentine, Bioinorganic Chemistry of Titanium, Chem. Rev. 112 (2012) 1863-1881. doi:10.1021/cr1002886.

[94] I.P. Parkin, R.G. Palgrave, Self-cleaning coatings, J. Mater. Chem. 15 (2005) 16891695. doi:10.1039/b412803f.

[95] A. Weir, P. Westerhoff, L. Fabricius, K. Hristovski, N. Von Goetz, Titanium dioxide nanoparticles in food and personal care products, Environ. Sci. Technol. 46 (2012) 2242-2250. doi:10.1021/es204168d.

[96] M.C.E. Lomer, C. Hutchinson, S. Volkert, S.M. Greenfield, A. Catterall, R.P.H. 
Thompson, J.J. Powell, Dietary sources of inorganic microparticles and their intake in healthy subjects and patients with Crohn's disease, Br. J. Nutr. 92 (2004) 947-955. doi:10.1079/BJN20041276.

[97] J. Coelho Filho, R. Moreira, P. Crocker, D. Levison, B. Corrin, Identification of titanium pigment in drug addicts' tissues, Histopathology. 19 (1991) 190-192. doi:10.1111/j.1365-2559.1991.tb00015.x.

[98] N. Lavi, Z.B. Alfassi, Determination of trace amounts of cadmium, cobalt, chromium, iron, molybdenum, nickel, selenium, titanium, vanadium and zinc in blood and milk by neutron activation analysis, Analyst. 115 (1990) 817-822.

doi:10.1039/AN9901500817.

[99] T.D. Richardson, S.J. Pineda, K.B. Strenge, T.A. Van Fleet, M. Macgregor, J.C. Milbrandt, J.A. Espinosa, P. Freitag, Serum Titanium Levels After Instrumented Spinal Arthrodesis, Spine (Phila. Pa. 1976). 33 (2008) 792-796.

[100] C. Engh, S. MacDonald, S. Sritulanondha, A. Thompson, D. Naudie, C. Engh, Metal Ion Levels After Metal-on-Metal Total Hip Arthroplasty: A Randomized Trial, Clin Orthop Relat Res. 467 (2009) 101-111. doi:10.1007/s11999-008-0540-9.

[101] Y. Nuevo Ordóñez, M. Montes-Bayón, E. Blanco-González, J. Paz-Jiménez, J.M. Tejerina-Lobo, J.M. Peña-López, A. Sanz-Medel, Metal release in patients with total hip arthroplasty by DF-ICP-MS and their association to serum proteins, J. Anal. At. Spectrom. 24 (2009) 1037-1043. doi:10.1039/b820339c.

[102] E. Dunstan, A.P. Sanghrajka, S. Tilley, P. Unwin, G. Blunn, S.R. Cannon, T.W.R. Briggs, Metal ion levels after metal-on-metal proximal femoral replacements: a 30year follow-up., J. Bone Joint Surg. Br. 87 (2005) 628-631. doi:10.1302/0301620X.87B5.15384.

[103] J. Ho, J. Mahajan, M. Taylor, A. Byers, P. Arauz, Y.M. Kwon, Metallosis in cemented titanium alloy total knee arthroplasty without apparent metal-on-metal articulation, Knee. 25 (2018) 728-731. doi:10.1016/j.knee.2018.04.013.

[104] I.P. McAlister, M.P. Abdel, Elevated Serum Titanium Level as a Marker for Failure in a Titanium Modular Fluted Tapered Stem, Orthopedics. 39 (2016) e768-e770. doi:10.3928/01477447-20160503-02.

[105] B.N. Stulberg, K. Merritt, T.W. Bauer, Metallic wear debris in metal-backed patellar failure, J. Appl. Biomater. 5 (1994) 9-16. doi:10.1002/jab.770050103.

[106] A.J. Hart, S.A. Sabah, A.S. Bandi, P. Maggiore, P. Tarassoli, B. Sampson, J. A. Skinner, Sensitivity and specificity of blood cobalt and chromium metal ions for predicting failure of metal-on-metal hip replacement, Bone Joint J. 93-B (2011) 13081313. doi:10.1302/0301-620X.93B10.26249.

[107] J. Jacobs, A. Skipor, L. Patterson, N. Hallab, W. Paprosky, J. Black, J. Gallante, Metal release in patients who have had a primary total hip arthroplasty, J. Bone Jt. Surg. 80A (1998) 1447-1458.

[108] L. Dorr, R. Bloebaum, J. Emmanual, R. Meldrum, Histologic, biochemical, and ion analysis of tissue and fluids retrieved during total hip arthroplasty, (1990) 82-95.

[109] J. Jacobs, C. Silverton, N. Hallab, A. Skipor, L. Patterson, J. Black, J. Galante, Metal release and excretion from cementless titanium-alloy total knee replacements.pdf, Clin. Orthop. Relat. Res. 358 (1999) 173-80.

[110] V.J. Rasquinha, C.S. Ranawat, J. Weiskopf, J.A. Rodriguez, A.K. Skipor, J.J. Jacobs, Serum Metal Levels and Bearing Surfaces in Total Hip Arthroplasty, J. Arthroplasty. 21 (2006) 47-52. doi:10.1016/j.arth.2006.05.005.

[111] L. Savarino, M. Greco, E. Cenni, L. Cavasinni, R. Rotini, N. Baldini, A. Giunti, Differences in ion release after ceramic-on- ceramic and metal-on-metal total hip replacement, J. Bone Jt. Surg. 88-B (2006) 472-476. doi:10.1302/0301620X.88B4.17333. 
[112] L. Savarino, G. Padovani, M. Ferretti, M. Greco, E. Cenni, G. Perrone, F. Greco, N. Baldini, A. Giunti, Serum ion levels after ceramic-on-ceramic and metal-on-metal total hip arthroplasty: 8-Year minimum follow-up, J. Orthop. Res. 26 (2008) 1569-1576. doi:10.1002/jor.20701.

[113] A. Bistolfi, A. Cimino, G.C. Lee, R. Ferracini, G. Maina, P. Berchialla, G. Massazza, A. Massè, Does metal porosity affect metal ion release in blood and urine following total hip arthroplasty? A short term study, HIP Int. 28 (2018) 522-530. doi:10.1177/1120700018762167.

[114] P.-A. Vendittoli, A. Roy, S. Mottard, J. Girard, D. Lusignan, M. Lavigne, Metal ion release from bearing wear and corrosion with $28 \mathrm{~mm}$ and large-diameter metal-onmetal bearing articulations: A FOLLOW-UP STUDY, J. Bone Jt. Surg. - Br. Vol. 92B (2010) 12-19. doi:10.1302/0301-620X.92B1.22226.

[115] D. Nam, J.A. Keeney, R.M. Nunley, S.R. Johnson, J.C. Clohisy, R.L. Barrack, Metal Ion Concentrations in Young, Active Patients Following Total Hip Arthroplasty with the Use of Modern Bearing Couples, J. Arthroplasty. 30 (2015) 2227-2232. doi:10.1016/j.arth.2015.06.025.

[116] J. Jacobs, A. Skipor, L. Patterson, N. Hallab, W. Paprosky, J. Black, J. Galante, Metal Release in Patients Who Have Had a Primary Total Hip Arthroplasty. A Prospective, Controlled, Longitudinal Study, J. Bone Jt. Surg. 80-A (1998) 1447-1458. doi:10.1016/0142-9612(85)90030-4.

[117] D. Granchi, L. Savarino, L. Savarino, G. Ciapetti, E. Cenni, R. Rotini, M. Mieti, N. Baldini, A. Giunti, Immunological changes in patients with primary osteoarthritis of the hip after total joint replacement, Bone Joint J. 85-B (2003) 758-64. doi:10.1302/0301-620X.85B5.13729.

[118] H. Quitmann, C. Wedemeyer, M. Von Knoch, K. Russe, G. Saxler, Titanium serum levels may remain elevated despite hip revision surgery for wear-through of an acetabular component, Biomed. Tech. 51 (2006) 27-29. doi:10.1515/BMT.2006.006.

[119] H. von Schroeder, D. Smith, A. Gross, R. Piliar, R. Kandel, R. Chernecky, S. Lugowski, Titanemia From Total Knee Arthroplasty, J. Arthroplasty. 11 (1996) 620625.

[120] S. Takai, N. Yoshino, Y. Kusaka, Y. Watanabe, Y. Hirasawa, Dissemination of metals from a failed patellar component made of titanium-base alloy, J. Arthroplasty. 18 (2003) 931-935. doi:10.1016/S0883-5403(03)00277-8.

[121] S.S. Leopold, R.A. Berger, L. Patterson, A.K. Skipor, R.M. Urban, J.J. Jacobs, Case Report Serum Titanium Level for Diagnosis of a Failed, Metal-Backed Patellar Component, J. Arthroplasty. 15 (2000) 938-943. doi:10.1054/arth.2000.6632.

[122] T.-K. Liu, S.-H. Liu, C.-H. Chang, R.-S. Yang, Concentration of metal elements in the blood and urine in the patients with cementless total knee arthroplasty, 185 (1998) 253-262.

[123] V. Ho, A. Arac, P. Shieh, Hearing and Vision Loss in an Older Man, JAMA Neurol. (2018) E1-2. doi:10.1302/0301. 